УДК 616-053.81: 611.127: 616-007-053.1:617-089.844:616-089.819.1

\title{
Особливості хірургічних і черезшкірних транскатетерних втручань у дорослих із вродженими вадами серця
}

\author{
Лебідь І. Г. ${ }^{1}$, Руденко Н. М. ${ }^{1,2}$, Лєбєдь $\in$. І.1,2, Кузьменко Ю. Л. ${ }^{1}$ \\ ${ }^{1}$ ДУ «Науково-практичний медичний центр дитячої кардіології та кардіохірургії МОЗ України» (Київ) \\ ${ }^{2}$ Національна медична академія післядипломної освіти імені П. Л. Шупика (Київ)
}

Щорічне збільшення кількості втручань у дорослих із вродженими вадами серця (ВВС) потребує вивчення віддалених результатів хірургічних та інтервенційних стратегій лікування даної патологіі.

Мета роботи - провести порівняльний аналіз різних стратегій надання допомоги дорослим пацієнтам при BBC.

Матеріали та методи. Ретроспективне дослідження проводилось із 01 січня 1999 р. по 31 грудня 2015 р. Виокремлено три періоди: 1999-2005, 2006-2010 та 2011-2015 pp. 382 дорослим виконано 450 кардіохірургіч-

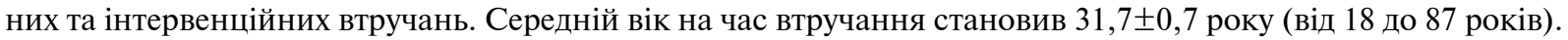
Осіб чоловічої статі було 190 (50\%), жіночої - 192 (50\%).

Результати та обговорення. При простих ВВС (ДМПП, ДМШП, ВАП) на початку всі втручання (100\%) були хірургічними, в подальшому до $35 \%$ вад усунуто ендоваскулярно. При КоАо в останні п’ять років у 54\% хворих вада усунута черезшкірним катетерним втручанням. На фоні поступового збільшення загальної кількості втручань на кондуїтах уже в другому періоді спостереження частка ендоваскулярних процедур (67\%) у таких хворих перевищила кількість виконаних хірургічних операцій.

Висновки. Виявлено зростання кількості інтервенційних втручань у дорослих із простими ВВС, коарктацією аорти та складними вадами (патології кондуїтів) при добрих віддалених післяопераційних результатах, що виводить дану стратегію на перше місце в системі надання кардіохірургічної допомоги таким хворим.

Ключові слова: дорослі, серце, вроджені вади, хірургія, ендоваскулярні втручання.

Удосконалення надання допомоги пацієнтам із вродженими вадами серця (ВВС) покращує у таких хворих виживаність і збільшує тривалість життя $[3,5,10]$. Щорічне зростання кількості хірургічних втручань на серці та магістральних судинах збільшує кількість хворих, які потребують повторних операцій і черезшкірних інтервенційних втручань із приводу вродженої патології серця вже в дорослому віці $[4,7,9]$. Популяційних системних досліджень, які відображають перебіг ВBC у дорослих і віддалені результати хірургічних та інтервенційних стратегій лікування даної патології, в Україні вкрай недостатньо, зазвичай вони поєднують пацієнтів різних вікових груп і проводяться у зв'язку із первинним нозологічним діагнозом [1, 2].

Мета роботи - провести порівняльний аналіз різних стратегій надання допомоги пацієнтам віком старше 18 років при вроджених вадах серця.

Матеріали та методи. Ретроспективне дослідження включало оцінку отриманих даних з історій хвороб усіх послідовних дорослих пацієнтів, які пройшли стаціонарне кардіохірургічне та інтервенційне лікування в період із 01 січня 1999 р. по 31 грудня 2015 р. Згідно з дизайном роботи, були виокремлені три періоди, пов'язані із системою організації кардіологічної та кардіохірургічної структури ДУ «НПМЦДКК МОЗ України». Період 1 (1999-2005 рр.) - етап спостереження, який відповідав результатам роботи Центру кардіохірургії новонароджених Національного інституту серцево-судинної хірургії імені М. М. Амосова НАМН України. Період 2 (2006-2010 рр.) - відокремлене формування ДУ «НПМЦДКК МОЗ України» та введення в роботу корпусу 1. Період 3 (20112015 pp.) - поєднана робота корпусу 1 та корпусу 2 «Клініка для дорослих». Отже, період 1 відповідав 7 рокам спостереження, періоди 2 та $3-5$ рокам динамічного контролю всіх дорослих із ВВС, яким були виконані хірургічні операції та/або черезшкірні втручання у віці старше 18 років. За досліджуваний період 382 дорослим пацієнтам у віці старше 18 років було виконано 450 кардіохірургічних та інтервенційних втручань із приводу ВВС. Середній вік на час втручання становив $31,73 \pm 0,70$ року (від 18 до 87 років). Осіб чоловічої статі було 190 (49,7\%), жіночої - 192 $(50,3 \%)$.

Всі кардіологічні та кардіохірургічні втручання 3 приводу вродженої патології серця (Interventions for congenital heart diseases), проведені дорослим хворим із BBC, були розділені на хірургічні втручання (операції, 
surgical operations), які визначалися як кардіохірургічні процедури, що вимагали або стернотомії або торакотомії, та черезшкірні транскатетерні втручання (transcateter interventions). Для порівняльного оцінювання різних стратегій надання допомоги були відібрані три основні напрями: прості ВВС (дефекти перегородок, відкрита артеріальна протока (ВАП)), процедури і втручання при коарктації аорти (КоАо) та ятрогенно сформованій патології (процедури та втручання, пов'язані з кондуїтом між правим шлуночком і легеневою артерією при патологічних аномаліях серця). Статистичний аналіз виконано з використанням пакета програм Statistica 6 (StatSoft Inc., США).

Результати. Удосконалення надання кардіологічної допомоги дорослим із ВВС призвело до збільшення як кількості пацієнтів, яким були проведені втручання з приводу ВВС, так і кількості самих втручань (рис. 1). Відзначено збільшення (практично в 4 рази) кількості пацієнтів: із 63 в 1999-2005 рр. до 256 - у 2011-20115 pр. Аналогічна динаміка (зростання кількості практично в 5 разів) була зареєстрована також і при проведенні втручань із приводу вродженої патології серця: із 66 в 1999-2005 рр. до $300-$ у 2011-2015 рр. Летальність у післяопераційному періоді протягом 30 днів перебування в стаціонарі за визначені періоди склала 1,6\%, 2,5\%, 0,4\% відповідно. У структурі діагнозів як серед «первинних», так i «передопераційних» дорослих досліджуваної групи переважали дефекти перегородок (ДП), які включали ДМПП та ДМШП (n=124; 33\% та n=109; 28\% відповідно) та вроджені вади аортального клапана (АК) (n=93; 24\% та n=87; 23\% відповідно).

При простих вадах серця та магістральних судин у першому періоді спостереження всі втручання (100\%) у дорослих досліджуваної групи були виконані тільки хірургічним шляхом (рис. 2). При подальшому формуванні та вдосконаленні надання кардіологічної та

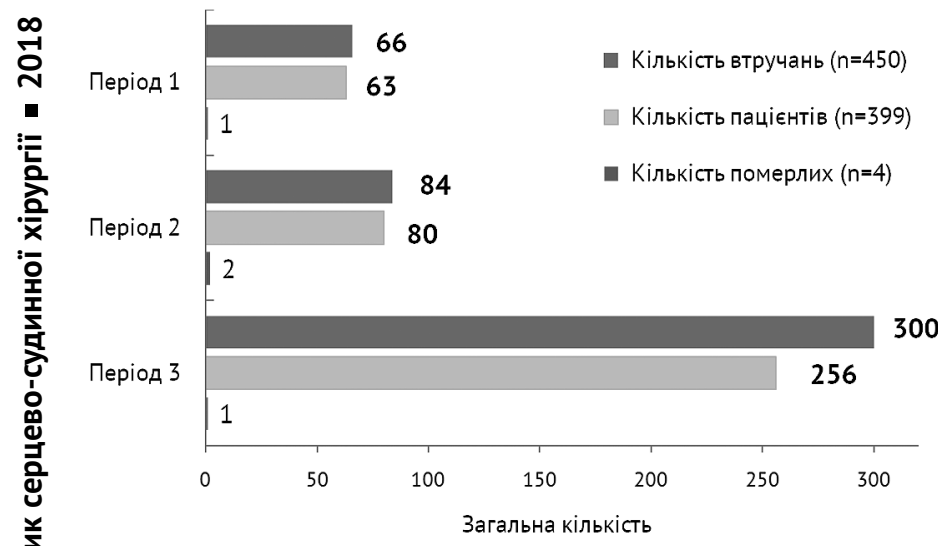

Рис. 1. Порівняльна структура кількості втручань, кількості пацієнтів і кількості померлих залежно від періодів спостереження у дорослих досліджуваної групи

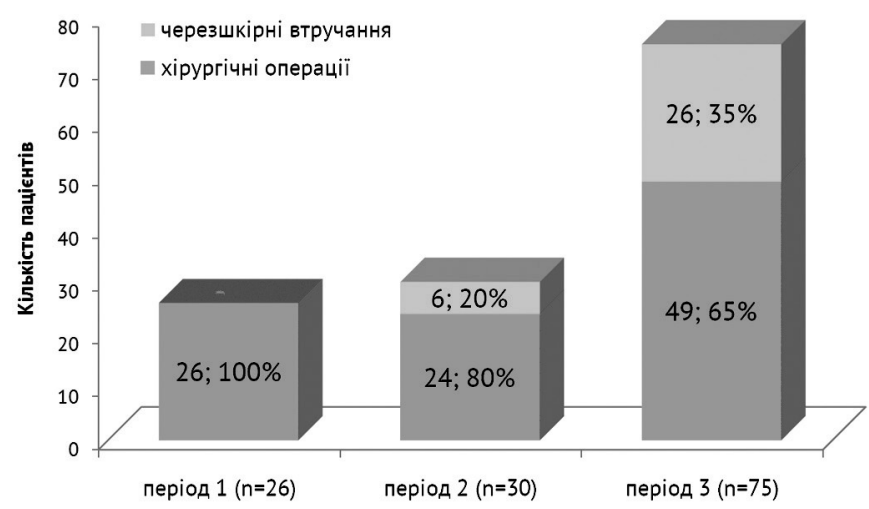

Рис. 2. Співвідношення кількості хірургічних операцій та черезшкірних ендоваскулярних втручань у дорослих із простими $B B C$ у різні періоди спостереження

кардіохірургічної допомоги таким пацієнтам уже у 2006-2010 рр. збільшилася до 1/5 частка хворих, яким усунення цих дефектів проведено черезшкірним інтервенційним шляхом із використанням різних типів оклюдерів. За останній період спостереження (20112015 рр.) зафіксовано значне зростання кількості черезшкірних ендоваскулярних втручань (закриття дефектів перегородок, ВАП), що склало $35 \%$ всіх втручань при даній патології. Це свідчить про зміну парадигми лікування таких вроджених аномалій зі зменшенням частки хірургічної корекції в бік інтервенційного закриття ВВС у дорослих віком старше 18 років.

Порівняльний аналіз кількості втручань із приводу КоАо залежно від періодів спостереження виявив зростання кількості втручань зі значною зміною від хірургічної стратегії лікування у дорослих у бік черезшкірних ендоваскулярних втручань (рис. 3). У 19992005 рр. усім дорослим хворим усування КоАо проводилося тільки шляхом хірургічної резекції звуженої частини аорти (100\%; n=12). Уже у 2006-2011 pp. $14 \%$ втручань у дорослих із даною аномалією аорти при-

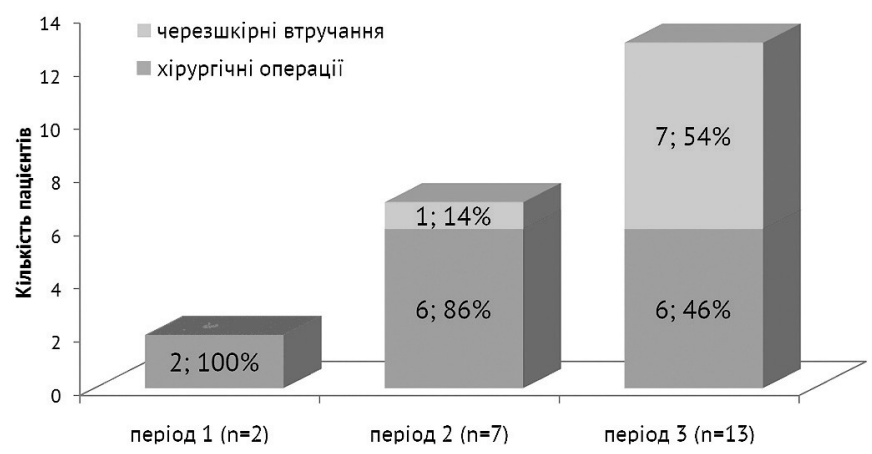

Рис. 3. Співвідношення кількості хірургічних операцій та черезшкірних ендоваскулярних втручань у дорослих із коарктацією аорти в різні періоди спостереження 
падало на ендоваскулярну балонну дилатацію КоАо. Важливою є зміна співвідношення між різними стратегіями лікування такої вади у 2011-2015 рр., де вперше зареєстровано переважання пацієнтів $(54 \% ; n=7)$, яким КоАо була усунута черезшкірним катетерним втручанням, над кількістю прооперованих хірургічно $(46 \% ; n=6)$.

Динаміка втручань із приводу патології кондуїту $(n=20)$ в дорослих за періоди дослідження характеризувалася поступовим збільшенням кількості самих втручань: від 3 у періоді 2 - до 17 у періоді 3 (рис. 4). Жодних втручань у періоді 1 не проводилось. У періоді 2006-2011 pр. кількість ендоваскулярних втручань у таких хворих перевищила кількість виконаних хірургічних операцій, однак при невеликій загальній кількості всіх втручань. Проте в 2011-2015 рр. на фоні значного зростання загальної кількості дорослих $(\mathrm{n}=17)$, яким проводилися втручання на кондуїтах, також переважну більшість (53\%) складали черезшкірні ендоваскулярні процедури на кондуїті (у вигляді балонної дилатації стенозу) порівняно з хірургічними операціями (заміна кондуїту). Отримані дані свідчать про значне збільшення ролі ангіографічних втручань при такій досить важкій патології, при значному збільшенні кількості таких хворих.

Одним із шляхів зниження летальності у дорослих із ВВС було більш широке використання черезшкірних інтервенційних втручань при наданні допомоги таким хворим. Аналіз розподілу всіх інвазивних втручань у дорослих із ВВС показав, що на ендоваскулярні втручання припадає понад $1 / 5$ всіх процедур. Якщо на початку дослідження практично всі втручання були представлені хірургічними операціями і тільки $1 \%$ припадав на ангіографічні інтервенційні втручання, то наступні роки виявили збільшення кількості таких процедур понад $13 \%$, а в останні роки спостереження їх частка у структурі всіх втручань зросла майже вдвічі, склавши $30 \%$.

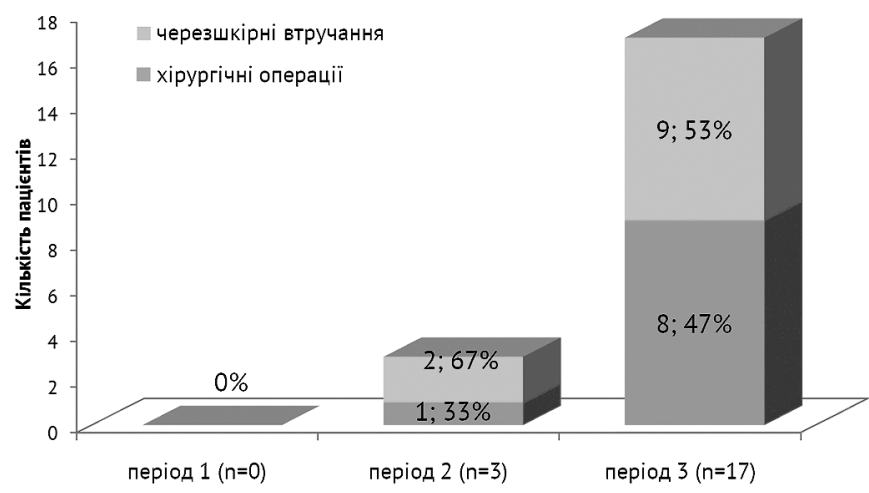

Рис. 4. Співвідношення кількості хірургічних операцій та черезшкірних ендоваскулярних втручань у дорослих із кондуїтами в різні періоди спостереження
Так, при простих ВВС (дефектах міжпередсердної та міжшлуночкової перегородки, ВАП) на початку спостереження всі втручання (100\%) у дорослих досліджуваної групи були виконані тільки хірургічним шляхом. При подальшому вдосконаленні кардіологічної та кардіохірургічної допомоги таким пацієнтам інтервенційні втручання були виконані у $35 \%$ дорослих хворих із представленою вродженою патологією. Порівняльний аналіз різних стратегій усунення КоАо протягом спостереження залежно від періодів виявив зростання кількості черезшкірних ендоваскулярних втручань і зменшення впливу хірургічної стратегії лікування у дорослому віці. В останні п'ять років спостереження співвідношення між різними стратегіями лікування такої вади вперше схилилось у бік переважання пацієнтів (54\%), яким КоАо була усунута черезшкірним катетерним втручанням. Аналогічна динаміка отримана у прооперованих дорослих із приводу патології кондуїту між правим шлуночком та легеневою артерією. Поступове збільшення загальної кількості втручань на кондуїтах протягом спостереження у дорослих із ВВС призвело до збільшення частки саме ендоваскулярних втручань (балонної дилатації стенозу кондуїту до $53 \%$ в останні роки) в системі кардіохірургічної допомоги таким хворим.

Отримана динаміка збільшення інтервенційних катетерних втручань при вродженій патології серця та магістральних судин у дорослих підтверджується світовим досвідом $[5,8,10]$. Так, Н. Uemura зі співавторами на підставі аналізу статистичних даних Національного інституту дослідження серцево-судинних наслідків (National Institute for Cardiovascular Outcomes Researchy) у співпраці з Товариством кардіоторакальної хірургії Великої Британії та Ірландії та Британського товариства вроджених вад серця показали щорічне збільшення як кількості пацієнтів, так і всіх втручань із приводу ВВС у даної когорти осіб, а починаючи з 2002 року це супроводжувалось поступовим і прогресуючим збільшенням частки катетерних процедур при всіх втручаннях [8]. На початку спостереження (у 2000 р.) було відмічено переважання хірургічних операцій у системі надання допомоги хворим із ВВС віком понад 18 років. Однак уже через 2 роки (у 2002 р.) кількість інтервенційних втручань перевищувала кількість хірургічних на 6\%, а протягом 10-річного спостереження ця різниця збільшилася до $26 \%$ при відсутності збільшення летальності - як 30-денної, так й у віддаленому післяопераційному періоді. Найбільш цікавим у представленому звіті є порівняльна динаміка 3 приводу усунення КоАо різними стратегіями. Якщо на початку спостереження кількість втручань, як хірургічних, так і транскатетерних, була рівною при досить низькому показнику летальності (менш ніж $1 \%$ при різних методиках), то в подальші роки спостерігалося значне збільшення са- 
ме інтервенційних втручань - майже в 9 разів за відсутності підвищення летальності в ранньому та пізньому післяопераційному періоді. Динаміка закриття ДМПП у дорослих була схожою, з досить значним збільшенням у бік інтервенційних процедур (майже в 4 рази).

Одноцентрове ретроспективне когортне дослідження 244 пацієнтів у дитячій лікарні Філадельфії (США), в якому порівнювались економічні витрати на різні методики закриття вторинного ДМПП на основі багатовимірного аналізу, продемонструвало більш високу вартість хірургічного лікування (60992 доларів США) порівняно $з$ транскатетерним шляхом (55841 доларів США на 2012 р.) [6]. Позитивними чинниками транскатетерного закриття є коротший термін перебування у лікарні, відносно менша вартість медикаментозного та інструментального забезпечення. Відмічено, що різниці витрат на фінансове забезпечення персоналу при обох методиках не було.

Висновки. Виявлено зростання кількості інтервенційних втручань у дорослих із простими ВВС (дефекти перегородок, відкрита артеріальна протока), коарктацією аорти та складними вадами (патології кондуїтів) при добрих віддалених післяопераційних результатах, що виводить дану стратегію на перше місце в системі надання кардіохірургічної допомоги таким хворим. Малоінвазивні ендоваскулярні процедури мають також економічний ефект завдяки зменшенню терміну перебування у стаціонарі загалом й у відділенні інтенсивної терапії зокрема, що зменшує вартість лікування таких хворих.

\footnotetext{
Автори заявляють про відсутність конфлікту інтересів.
}

\section{Література}

1. Алгоритм діагностики пізніх ускладнень після радикальної корекції тетради Фалло з показаннями до повторного хірургічного втручання / Горячев А. Г., Дикуха С. О., Наумова Л. Р. та ін. // Вісник серцево-судинної хірургіï. - 2017. - № 2 (вип. 28). - С. 56-62.

2. Досвід транскатетерного лікування дефектів міжшлуночкової перегородки / Ящук Н. С., Дітківський I. O., Черпак Б. В. та ін. // Вісник серцево-судинної хірургіï. - 2017. - № 1 (вип. 27). - С. 94-100.

3. Лебідь І. Г. Поширеність вроджених вад серця і магістральних судин у дорослих // Кардіохірургія та інтервенційна кардіологія. - 2017. - № 1. - С. 6-12.

4. Berdat P. A., Immer F., Pfammatter J.P. Reoperations in adults with congenital heart disease: Analysis of early outcome // Int J Cardiol. - 2004. - Vol. 93. - P. 239-245.

5. Cardiac surgery in adults with high-surgical complexity CHD: Results of a network collaborative programme / Gilad V., Santoro F., Ribera E. et al. // Cardiology in the Young. - 2018. - Vol. 28 (1). - P. 101-107.

6. Cost comparison of transcatheter and operative closures of ostium secundum atrial septal defects / O'Byrne M. L., Gillespie M. J., Shinohara R. T. et al. // American heart journal. - 2015. - Vol. 169. - №. 5. - P. 727-735. e2.

7. Challenges of congenital heart disease in grown-up patients / Schwerzmann M., Schwitz F., Thomet C. et al. //. Swiss medical weekly. - 2017. - Vol. 147. -P. w14495.

8. Uemura H. Surgical and catheter procedures in adult congenital heart disease: simple national statistics of the UK tell us something // General thoracic and cardiovascular surgery. - 2013. - Vol. 61 (7). - P. 376-389.

9. Chance of surgery in adult congenital heart disease / Verheugt C. L., Uiterwaal C. S., Vaartjes I. et al. // Eur J Prev Cardiol. - 2017. - Vol. 24 (12). - P. 1319-1327.

10. Warnes C. A. Adult congenital heart disease: the challenges of a lifetime // European heart journal. - 2017. - Vol. 38 (26). - P. 2041-2047.

\title{
Features of surgical and endovascular procedures in adults with congenital heart defects
}

\author{
Lebid I. H. ${ }^{1}$, Rudenko N. M. ${ }^{1,2}$, Liebied Y. I. ${ }^{1,2}$, Kuzmenko Yu. L. ${ }^{1}$ \\ ${ }^{1} \mathrm{GI}$ «The scientific practical children's cardiac center» (Kyiv) \\ ${ }^{2}$ National Academy of Postgraduate Education named after P. L. Shupyk (Kyiv)
}

Annual increase the number of interventions in adults with congenital heart defects (ACHD) requires the estimation of long-term follow up surgical and interventional treatment strategies for this pathology.

The goal was to estimate different strategies for cardiac surgery care in ACHD

Matherial and Methods. This retrospective review included an analysis of medical case reports of all patients aged 18 years and older during period from 01 Jan 1999 to 31 Dec 2015. There were 3 periods: Period 1 - from 1999 to 2005 , Period 2 - from 2006 to 2010 , Period 3 - from 2011 to 2015 . 450 surgical procedures were performed in 382 patients over the study period. Mean age at the time of intervention was 31.7 \pm 0.7 years; $18-87$ years), $190(50 \%)$ male, 192 (50\%) - female.

Results and discussion. At the beginning of research $100 \%$ interventions for adults with simple CHD (ASD, VSD, PDA) were surgical, with increasing amount endovascular interventions till $35 \%$ in follow period. At the 3 period $54 \%$ patients with Coarctation of aorta had endovascular interventions. There was prevalence number of patients with conduit pathology after endovascular interventions in 2 period $(67 \%)$ and 3 period (53\%) compared with surgery strategy.

Conclusions There was increasing the number of endovascular intervention in adults with simple CHD, coarctation of aorta and conduit pathology with good postoperative follow-up period, what takes this strategy into the first place in cardiac care system for these patients.

Key words: adults, congenital heart defects, surgery, procedures, endovascular intervention. 


\title{
Особенности хирургических и чрескожных транскатетерных вмешательств у взрослых с врожденными пороками сердца
}

\author{
Лебедь И. Г. ${ }^{1}$, Руденко Н. Н. ${ }^{1,2}$, Лебедь Е. И',2, Кузьменко Ю. Л. ${ }^{1}$ \\ 1 ГУ ««Научно-практический медицинский центр детской кардиологии и кардиохирургии МЗ Украины» (Киев) \\ ${ }^{2}$ Национальная медицинская академия последипломного образования имени П. Л. Шупика (Киев)
}

Ежегодное увеличение количества вмешательств у взрослых с врожденными пороками сердца (ВПС) требует изучения отдаленных результатов хирургических и интервенционных стратегий лечения данной патологии. Цель работы - провести сравнительный анализ различных стратегий оказания помощи взрослым пациентам при ВВС.

Материалы и методы. Ретроспективное исследование проводилось с 1 января 1999 по 31 декабря 2015 г. Выделено три периода (1999-2005, 2006-2010 и 2011-2015 гг.). 382 взрослым было выполнено 450 кардиохирургических и интервенционных вмешательств. Средний возраст на момент вмешательства составил $31,7 \pm 0,7$ года (от 18 до 87 лет). Лиц мужского пола было 190 (50\%), женского - 192 (50\%).

Результаты и обсуждение. При простых ВВС (ДМПП, ДМЖП, ОАП) в начале исследования все вмешательства $(100 \%)$ были хирургическими, в дальнейшем до $35 \%$ пороков устранено эндоваскулярно. При КоАо в последние пять лет 54\% больным порок был устранен чрескожным катетерным вмешательством. На фоне постепенного увеличения общего количества вмешательств на кондуитах уже во втором периоде наблюдения доля эндоваскулярных процедур (67\%) у таких больных превысила количество выполненных хирургических операций.

Выводы. Отмечен рост количества интервенционных вмешательств у взрослых с простыми ВВС, коарктацией аорты и со сложными пороками (патологии кондуита) при хороших отдаленных послеоперационных результатах, что выводит данную стратегию на первое место в системе предоставления кардиохирургической помощи таким больным.

Ключевые слова: взрослые, сердие, врожденные пороки, хирургия, эндоваскулярные вмешательства. 